\title{
Singapore and Sumatra's Westkust as a Malay Writing and Journalism Hub before World War II
}

\author{
Mohd Amirul Akhbar Mohd Zulkifli
}

\begin{abstract}
This paper attempts to identify and assess Singapore and Sumatra's Westkust (West Sumatra) as the centre for Malay intellectual activities before World War II. The present literature has not focused on this subject. Therefore, what this paper does is examine the context of Malay publishing and journalism and the growth of newspapers. It tries to answer why Malay journalism and writing thrive by identifying factors from geography, to colonialism to the cultural. In so doing, two factors emerged as critical to the growth of Malay writing and journalism, that is, trade, and the consciousness for information and knowledge and rejection towards Pax Neerlandica.
\end{abstract}

Index Terms - Colonialism, journalism, Malay newspaper, publishing.

\section{INTRODUCTION}

In Singapore, European expansion and the Malay diasporas met. Europe's command of communication and information interfaced with the new found expression of the Malay through contemporary information technologies. Singapore was the outstanding example of the creation of late nineteenth century colonial communications. It prepared new channels of information within the indigenous realm [1]. Singapore was the home of the mission presses; but more significant, the home of a network of Malay Muslim publishers. These were largely controlled by the Javanese settled in Kampung Glam. After 1840, 85 per cent of books in Malay came from the island.

Peaking in the 1890s, the Malay Muslim publishers produced a wide range of books of instruction, court chronicles, and verse. Of these, the syair was perhaps the most important. Harper compares it to common speech and well-suited to being read aloud. Chains of distribution were created by mail-order catalogues, agents, vernacular books published by the government or the missions, were commercial products sold in shops as a luxury item. They allowed courtly text to be uprooted from their social context and distributed amongst everyone who could afford them. The new technology aided the emergence of a new idea of literature - contemporary, authored by named individuals, and read as an internal mental process, rather than uttered as a social transaction. In 1890, the fortnightly output of the Singapore Muslim presses alone eclipsed the entire production in literary manuscripts to that date of several centuries, and this does not take onto account the unregistered publications of other printers [2].

Manuscript received August 9, 2015; revised March 1, 2016.

Mohd Amirul Akhbar Mohd Zulkifli is with the Institute of Journalism Studies, Faculty of Communication and Media Studies, University Technology MARA, Malaysia (e-mail: amirul@uitm.edu.my).
Singapore was at the centre of colonial communications. The regions surrounding it as in Indochina and the Dutch East Indies created British insecurity to the colonial power in Singapore. The colonials did not hold a monopoly. Indigenous systems and identities thrive with the fusion of technologies arrived from Europe.

Meanwhile in West Sumatra the research toward the development of printing development specifically the newspapers industry was not extensive enough done. Perhaps the most comprehensive one was by Ahmat Adam under the title The Vernacular Press and the Emergence of Modern Indonesian Consciousness 1855-1913 which was published in 1995. According to Ahmat Adam [3] the research on the development of newspapers industry in West Sumatra before World War 2 was too little. In some cases the accuracy of information provided by some researchers can be questioned in term of the names of the newspapers, year of publications as well as the operators who initiated the printing press in Sumatra's Westkust during the Dutch era.

For the purpose of this research, the newspapers development in Sumatra's Westkust can be divided into four decades from 1900 to 1941. Towards the end of the decade has witnessed an increased of awareness among the Indonesian largely and Minangkabau's specifically on Dutch imperialism policy. For the Minangkabau's in Sumatra's Weskust issue on "development" was the central theme during the first half of $20^{\text {th }}$ century. It was merely a reflection toward the policy implemented by the Dutch especially under the repressive persdelict cases which suppressed the journalists since 1906 until 1930s.

\section{Singapore's Jawi Peranakan AND the Colonial GOVERNMENT}

In an effort to understand the newspaper industry in the region, it must be traced back to the history of its development in the vicinity of the Malay Archipelago. Printing activities that took place since the 15 th century was a catalyst for the development of knowledge. It includes knowledge in various fields such as religious, political and economic aspects involving. Another feature of the newspaper publishing that can be highlighted is that it is accompanied by or undertaken by almost all countries in the Malay Archipelago, even though at first dominated by the colonial government. Such as, the Spanish in Philippines, the Dutch in Indonesia and British in Malaya. In the regional context, Indonesia for instance (refer to West Sumatra), newspapers have been published since 1859. It is recognized as one of the oldest publications compared to other districts. It is now also certified as a district with a lot of newspapers 
and magazines.

The contours of the early development in the newspapers industry in Malaya, Singapore and Indonesia at the close of the nineteenth century were contributed by several factors. Among them was due to the exposure of Islam that became the catalyst for the inclusion of reading aspects and printed materials, the role played by Jawi Peranakan which had mobilised the newspapers publishing in Malaya and Singapore, especially in the aspect of socialization, competition in the newspaper industry group with another equally important factor that was the policies implemented by the British in Malaya and the Dutch in Batavia. From the historical perspective, the Malay newspapers industry began to grow since the end of the 18th century until the 19th century which saw Singapore as the heart of the existence of the Malay language newspapers [4] Apart from the rapid growth that swept the Malay newspaper industry, the period from 1867 to 1941 also saw the same thing for the Chinese-language newspapers and India [5].

The rapid development that occurred in Singapore, particularly in the 19th century can be seen in terms of trade activities that had uplifted its image as an entrepot. Clearly it shows the importance of the maritime aspects especially that involved the world's two superpowers - the British and Dutch. There are scholars who acknowledged that the pace and bustle that exists in Singapore was similar as Malacca in the 15 th century. Not only it became the focal point of traders from Malay Archipelago, but also emerged as the Islamic center. The situation shows the increased in the Muslim community, whether Malay, Arab and Indian Muslims in Singapore. According to Roff (1974) despite of the differences of their own social and economic backgrounds, but in terms of language, they used the Malay language in social interaction. The fact is that even though Singapore is owned by the British since 1819 , but it is not a barrier to the presence of other ethnic groups such as Chinese, Javanese, Boyanese, Bugis and Jawi Peranakan. As assert by Roff: "Eighty two years later in 1901, it was the temporary or permanent home of 23,060 peninsular Malays, 12,335 "other natives of the Archipelago," almost a thousand Arabs, and about 600 Jawi Peranakan. The total population of all races was 228,555 , of whom 72 percent were Chinese. Of the 36,080 Malaysians in Singapore, more than 26,000 including the greater proportion of the Javanese and other immigrants from the Archipelago, lived within the limits of the municipality [6]. Jawi Peranakan, first published in 1876 in Singapore was the starting point of the Malay-language newspaper publishing Through the publication it proves that the Malay language as the lingua franca certified since the days of the Malacca Sultanate (1400-1511) was certainly influential and reach not just in Singapore but also includes the news that took place on the island of Indonesia and Brunei as asserts by Ahmat Adam (1994). His explanation especially on the circulation of Jawi Peranakan showed the dynamism of the Malay-language newspapers that was able to adapt with the British imperialism namely the constraints of economic and law imposed at that time. But it did not stop the distribution of the Malay Archipelago. As we mentioned at the beginning of the discussion, the development of newspaper production were influenced by several factors.
According to A.M. Iskandar (1976), one of the main factors contributing to the issue of Jawi Peranakan is the knowledge factor. In term of the production of Jawi Peranakan, mainly focus on the spread of Islam among the Malays [7] This can be understood based on the background of Singapore, especially in the 19th century which became the center of Islamic learning. Thus became attractive to many parties in the Malay Archipelago, especially the Malays from Malaya, Indonesia and the Indian Muslims and Arabs.

\section{THE HADHRAMI'S MALAY NEWSPAPER AND UTUSAN MELAYU}

Singapore manifested the Malay fervour in speech and expression. Two newspapers named Utusan Melayu ware published there. The first was in 1907 by entrepreneur William Makepeace as the Malay version of the English newspaper the Singapore Free Press. The latter was editorially led by Makepeace. But from 1 May 1910, Muhammad Eunos Abdullah led the formation of a company called Utusan Melayu Limited with a capital of $\$ 5,000$ to buy over Utusan from Makepeace.

The second Utusan Melayu was published in 1939. The second (and present organ in the form of Utusan Malaysia), together with the 'brother' newspapers as in Warta Malaya, Majlis and later Warta Negara galvanized Malay sentiment and opinion in encountering the British in the wake and aftermath of World War II. Both newspapers fulfilled the need for Malays in Singapore and Malaya to develop a voice.

Perhaps no other periodical has been written so much than Al-Imam, published in Singapore from July 1906. Al-Imam embodied and exemplified the biculturalism, within a shared modernist Islamic framework, of Hadrami/Malay relations in the first years of the new century. Its protagonists included the Azhar-trained Minangkabau, Muhammad Tahir Jalaluddin, the Melaka-born Sayyid Shaykh al-Hadi, the Cirebon-born muwallad Shyakh Muhammad Salim al-Kalali, the Singapore-born, Mekah-educated 'alim Haji Abbas Muhammad Taha, and the cosmopolitan immigrant Sayyid Muhammad 'Aqil Yahya [8].

Well aware of the location of cultural-geographical location of their journalistic-intellectual enterprise, the editorial in the first issue of Al-Imam, titled "The Proper Task: What is most needed for Our People," al-Hady set out their stall. He wrote that what "our people" - implying the Malays and other indigenous Muslims of Southeast Asia - most needed were skills of craftsmanship and agriculture, education to "rescue us from the slough of apathy and indolence" and to help us united for the common good, what would strengthen and realise all these desires was "knowledge of the commands of our religion."

The 1930s saw a new development based in Singapore that of the Malay language Hadrami journalism, of what Roff describes as the emergence of large-scale, metropolitan daily and weekly newspapers and journals of comment, read widely throughout the peninsula and contributing importantly to the growth of Malay political consciousness. The trend setter that could have influenced much of the journalistic genre in the peninsula Singapore-based Warta 
Malaya beginning January 1932. Metropolitan in outlook, Warta Malaya became the dominant Malay paper in the decade that followed. Warta Malaya was established as a commercial enterprise by Sayyid Husayn Alsagoff. The success of Warta Malaya was followed its Sunday companion, Warta Ahad in mid 1935, and the following year, a weekly entertainment paper, Warta Jenaka (Roff, 2009: 171).

In 1934, Singapore witnessed a second major Hadrami-funded Malay newspaper, the weekly Lembaga Malaya, owned by Sayyid 'Alwi Albar, and edited for its first two years by Onn Jaafar. Some months later the Warta Malaya was joined by the daily Lembaga Malaya. The two newspapers, which later moved to Johor Baru, was very significant to the growth of Malay identity. More pro-Malay in temper than anti-colonial, their competitor was the twice-weekly Kuala Lumpur-based Majlis which lasted between 1931 to 1935 . Singapore carried the political change from Hadhramaut itself.

\section{EARLy PRESS DEVELOPMENT IN SUMATRA's WESTKUST}

The earliest newspaper industry in Sumatra's Weskust can be traced as early in 1859 specifically in Padang with the birth of the Dutch initiated known as Padangsch Nieuws-en Advertentieblad or Sumatra Courant. The effort to expand the newspaper industry in local language being realized in December 1864 when A.W.A Scholte initated the printing of Bintang Timoer. In August 1871 Bintang Parnama was published by L.N.H.A Chatelin in Padang. The common dilemmas faced during the early years by the publishers was on low readerships among the locals which caused the closure of both newspapers in 1866 (Bintang Timoer) and 1872 (Bintang Parnama).

Between 1900 to 1910 , the newspaper industry in Padang has gained the local touched especially from the ingenious namely Datoek Soetan Maharadja and Dja Endar Moeda. It also witnessed the rapidity development in newspapers industry in Padang and became part of the daily life of the Minangkabau's. At this juncture the issues published in the press merely discussed on the inhumane treatment to the locals especially and the Javanese islands at large. The Dutch administration was also in alarmed of the influenced of Islamist movement and influenced especially from Turkey. Despite of the closed monitoring by the Dutch administration on the local press, the industry flourished tremendously as there were about more than 11 newspapers being published in Padang. The similarities found between the Sumatra's Westkust and Singapore on the newspapers industry are (1) trade, and (2) the consciousness for information and knowledge which derived from the Islamist Reformist.

\section{CONCLUSION}

The journalistic activities gravitating from Singapore and Sumatra's Westkust shaped the context of colonial rule, whether British or Dutch, leading to the establishment of ethnic or 'racial' categories determining views of economic function and cultural propensities [8]. Interestingly the
Hadrami involvement in Malay (and Arabic language) journalism from Singapore in the first four decades of the twentieth century demonstrated values pointing toward either 'assimilating' or engaging in 'identity maintenance' [8] Singapore was the abode due to its centrality in the Malay world. It was a world of diaspora where the Malay-Muslim population converged to form a vibrant society ever conscious of identity but at the same time liberal enough to accommodate one another. One mode of this accommodation is through publishing and journalism. Meanwhile Padang can be identified as the heart of reformation and modernization which act as a catalyst among the locals. Toward the end of 1930s the newspapers industry has expanded to other areas namely Padang Panjang, Bukit Tinggi, Payakumbuh, Sawah Lunto, Batusangkar, Maninjau, Sulit Air, Solok, Lintau and Pariaman.

\section{ACKNOWLEDGMENT}

In completing the paper, the author wishes to thank to Prof. Dr. Ahmad Murad Merican for his insight and valuable comments pertaining to the preliminary discussion made in 2014. Special thanks to the Dean of Faculty of Communication and Media Studies, University Technology MARA for the support and encouragement given throughout the development stage towards the end. It was not an easy task especially when dealing with a historical study blended with journalism development in the Malay Archipelago specifically in Singapore and Sumatra, Indonesia. The acknowledgement lastly goes to Prof. Dr. Ahmat Adam and Prof. Dr. Mohd Safar Hashim for their early works pertaining to the communication and journalism in South East Asia. Without such works, it would be impossible for the author to galvanize the discussion which combined two different colonial settlements that were the British in Singapore and the Dutch in Sumatra, Indonesia.

\section{REFERENCES}

[1] T. N. Harper, "The state and information in modern southeast Asia history," in Yao Souchou, Ed. House of Glass: Culture, Modernity and the State in Southeast Asia, Singapore: Institute of Southeast Asia Studies, 2001, pp. 213-240.

[2] I. Proudfoot, Early Malay Printed Books, Kuala Lumpur: The Academy of Malay Studies and The Library, University of Malaya, 1993.

[3] A. Adam, Sejarah dan Bibliografi Akhbar dan Majalah Melayu Abad Kesembilan Belas, Bangi: Universiti Kebangsaan Malaysia, 2012.

[4] A. F. Yassin, Akhbar dan Kuasa: Perkembangan Sistem Akhbar di Malaysia Sejak 1806, Kuala Lumpur: Penerbit Universiti Malaya, 1996.

[5] M. S. Hasim, Akhbar dan Kuasa: Perkembangan Sistem Akhbar di Malaysia Sejak 1806, Kuala Lumpur: Penerbit Universiti Malaya, 1996.

[6] W. R. Roff, The Origins of Malay Nationalism, Kuala Lumpur: University of Malaya Press, 1974, p. 33.

[7] A. M. Iskandar Haji Ahmad, Persuratkhabaran Melayu 1876 - 1968, Kuala Lumpur: Dewan Bahasa dan Pustaka, 1976.

[8] W. R. Roff, Studies on Islam and Society in Southeast Asia, Singapore: NUS Press, pp. 167, 170, 173-174, 2009.

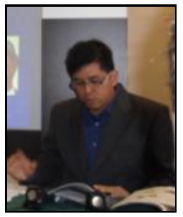

Mohd Amirul Akhbar received his bachelor of communication (hons) (specialization in Journalism and minor in International History and Political Affairs) from the Universiti Sains Malaysia in 1997, and a master of science (new media technology) from the Universiti Teknologi MARA in 2001. His areas of interest and specialization are journalism, political communication, 
media law \& new media technology. His first job was as a broadcasting journalist cum assistant producer with Metro Vision. He later joined the Board of Engineers Malaysia (BEM) as a publication officer and deal directly with the engineering professions in Malaysia. His stint in the office of BEM proved to be a good foundation for an early exposure in his dealings with the Public Sectors. He also has vast experience in handling trainings, publications as well as administrative matters. Prior to that, he was attached to the Netscape Learning Center (UTUSAN EDUCATION PORTAL) as Writer. With his vast experience he was also involved in translating the content for the World Book of Encyclopedia for Dewan Bahasa dan Pustaka (DBP).

Currently he is the director of the Institute of Journalism Studies Universiti Teknologi MARA (UiTM) and holds the position as an assistant professor of Journalism. He was also the former UiTM Radio Manager. He was the Coordinator for the Center of Academic Affiliation since 2007 until 2010. He was also the Faculty's Web Manager and actively involves in various committees at the faculty, university and national level. Among the committees are; Publication and Seminar Committee, Quality Assurance Committee, I-Learn and Web Portal Committee. Previously he was attached to the Universiti Tun Abdul Razak (UNITAR) and held the position as the Head of the Center for Languages and General Studies.
He helped the university in achieving and developing programmes such as the UNITAR Marketing \& Promotion, Corporate Event, Corporate Training Program, ISO 9001: 2000, and Internship Database, Student Administration System (Faculty of Humanities and Social Sciences) as well as involved in developing the academic programs. He teaches mass communication \& management courses for the University and External Institutions. Among the courses taught; media law, regulations and ethics, interpersonal and communication skills, advanced desktop publishing, newspaper management, \& government studies. He was also attached to Hartford Management Center and responsible for Master of Art (Communication - A Distance Learning Program) offered by Leicester University. He was also attached as a consultant to the International Society of Business Administrators - UK - ABE (ISBA), and act as the external examiner for UK - ABE programmes in Malaysia. 